\title{
Onset of calving at supraglacial lakes on debris-covered glaciers of the Nepal Himalaya
}

\author{
A. SAKAI, ${ }^{1}$ K. NISHIMURA, ${ }^{1}$ T. KADOTA ${ }^{2}$ N. TAKEUCHI ${ }^{3}$ \\ ${ }^{1}$ Graduate School of Environmental Studies, Nagoya University F3-1(200), Chikusa-ku, Nagoya 464-8601, Japan \\ E-mail: shakai@nagoya-u.jp \\ ${ }^{2}$ Japan Agency for Marine-Earth Science and Technology, 2-15 Natsushima-cho, Yokosuka 237-0061, Japan \\ ${ }^{3}$ Chiba University, 1-33 Yayoi-cho, Inage-ku, Chiba 263-8522, Japan
}

\begin{abstract}
Field surveys of supraglacial ponds on debris-covered glaciers in the Nepal Himalaya clarify that ice-cliff calving occurs when the fetch exceeds $\sim 80 \mathrm{~m}$. Thermal undercutting is important for calving processes in glacial lakes, and subaqueous ice melt rates during the melt and freeze seasons are therefore estimated under simple geomorphologic conditions. In particular, we focus on the differences between valley wind-driven water currents in various fetches during the melt season. Our results demonstrate that the subaqueous ice melt rate exceeds the ice-cliff melt rate when the fetch is $>20 \mathrm{~m}$ and water temperature is $2-4^{\circ} \mathrm{C}$. Calculations suggest the onset of calving due to thermal undercutting is controlled by water currents driven by winds at the surface of the lake, which develop with expanding water surface.
\end{abstract}

\section{INTRODUCTION}

Many glacial lakes have expanded in recent years due to glacier terminus retreat. Glacier- or moraine-dammed glacial lakes are distributed widely across the globe (Thórarinsson, 1939, 1957; Liestøl, 1956; Post and Mayo, 1971; Lliboutry, 1977; Lliboutry and others, 1977a,b; Kirkbride, 1993) and sometimes produce glacier outburst floods (GLOFs), threatening human life and livelihood and causing damage to infrastructure and industry, including road networks and hydropower installations (LIGG/WECS/NEA, 1988; Richardson and Reynolds, 2000). Many of these glacial lakes were only small supraglacial ponds some decades ago. Ponds on debris-covered glaciers at present could eventually develop into large moraine-dammed glacial lakes. Thus, clarification of the expansion processes of supraglacial lakes is useful for understanding lake development and for anticipating outburst floods.

Rapidly developing large glacial lakes often expand by calving of glacier ice (Sakai and others, 2000a, 2003), whereas small ponds (of the order of $30 \mathrm{~m}$ in length) expand slowly due to ice-cliff melting (Sakai and others, 2000b). Based on observations at several glacial lakes in New Zealand, Kirkbride (1993) has confirmed that the transition from melting to calving termini plays an important role in the onset of the rapid expansion of glacial lakes.

Several studies have found that thermo-erosional notch growth at the waterline is the rate-controlling mechanism during subaerial calving (Kirkbride and Warren, 1997; Benn and others, 2001; Warren and Kirkbride, 2003; Diolaiuti and others, 2005; Röhl, 2006, 2008; Benn and others, 2007). Kirkbride and Warren (1997) found at Maud Glacier, New Zealand, that thermo-erosional notching, calving at the waterline, flake calving, full-height slab calving and subaqueous calving form a repetitive cycle of processes controlled by the rate of waterline melting. Benn and others (2001) have reported that waterline melting can exert a strong influence over calving rates. They observed supraglacial lakes at Ngozumpa Glacier, Nepal Himalaya, and also reported spatial differences in the calving process. Diolaiuti and others (2005), from observations at Miage glacier, Italian
Alps, have suggested that the calving of ice cliffs is controlled by the development of deep notches at the waterline. Warren and Kirkbride (2003) have also proposed that water temperature may be a key variable in explaining the calving speeds in terms of a thermal undercutting mechanism in New Zealand and Argentina.

Röhl (2006), who has directly measured thermal undercutting at Tasman Lake, New Zealand, concluded that the calving rate is directly controlled by the rate of thermal undercutting, and has implied that the process of thermal undercutting plays a central role in the transition from mere melting to calving termini. Warren and Kirkbride (1998), Benn and others (2001) and Haresign and Warren (2005) have also observed the thermal undercutting rate. The above results by several researchers suggest that thermal undercutting acts as a trigger for lacustrine calving.

The limnological condition is an important factor in the process of thermal undercutting. Based on their observations in Canada, Josberger and Neshyba (1980) suggested that iceberg melt-driven convection is important for subaqueous iceberg melt. Russell-Head (1980) and Eijpen and others (2003) investigated subaqueous ice melting in laboratory experiments. Russell-Head (1980) analyzed the relationship between subaqueous ice melt rate and ambient water temperature. Based on their free-convection experiments, Eijpen and others (2003) concluded that not only water temperature but also density-driven water currents significantly affected the rate of subaqueous ice melting. Martin and others (1978) investigated wave-induced ice-wall melting. These previous studies focused only on the effect of limnological phenomena such as water currents or water temperatures on the subaqueous ice melt. The effects of wind-driven water convection on subaqueous ice melt (thermal undercutting) at glacial lakes have not received close attention to date.

In the high Himalayan mountains, valley winds are strong during the daytime (Inoue, 1976; Chikita and others, 1997). Average daily maximum wind velocity can reach $>10 \mathrm{~m} \mathrm{~s}^{-1}$ during the melt season (June-September) (Yamada, 1998). However, the effect of water currents driven by valley winds on thermal undercutting of glacier terminus ice cliffs has not 
been clarified. Since observation at the front of the glacier terminus ice cliff can be very dangerous due to sudden collapse of ice cliffs or falling debris, we estimated water currents driven by valley winds using simulations. To examine the contribution of water currents, driven by valley winds in the variable topography of proglacial lakes, to the onset of calving due to thermal undercutting, we calculated the wind velocity distributions according to varying fetches, as well as the wind-driven lake surface currents.

\section{STUDY AREA AND SUMMARY OF FIELD RESEARCH}

In the Khumbu region of the Nepal Himalaya, large valley glaciers several kilometers long have a mostly debriscovered ablation area and occupy $>80 \%$ of the glacierized areas (Moribayashi, 1974). Debris-covered glaciers advanced to approximately $4500 \mathrm{~m}$ a.s.l. in the Little Ice Age (LIA) between the 16th and 19th centuries. Several large moraine-dammed glacial lakes have expanded since the LIA and continue to expand at the termini of debris-covered glaciers in the Himalaya (Yamada, 1998; Ageta and others, 2000; Richardson and Reynolds, 2000; Iwata and others, 2002; Komori and others, 2004; Quincey and others, 2005). The glacial lakes are surrounded and dammed by end moraines which formed during the LIA. Lake water overtopping a moraine can carry sufficient energy to break through a moraine dam. Overtopping may occur as a result of a large wave generated by a huge snow or ice mass falling into the lake (e.g. a snow or glacier avalanche) or by advancing, sliding and calving of the glacier (Costa and Schuster, 1988). Earthquakes, too, may act as external triggers contributing to lake outbursts since moraine-damming lake waters can contain not only debris but also ice, and earthquakes will decrease the strength of the moraine (Yamada, 1998).

Chikita and others $(1997,1999)$ found that powerful water convection is caused by strong valley winds. Chikita (2007), using a numerical simulation of wind over the lakes, indicated that the thermal structure of glacial lakes is affected by the surrounding topography. This suggests that water convection due to strong valley winds has to be taken into account when examining the process of thermal undercutting.

Field observations were carried out in the ablation area of four debris-covered glaciers, Ripimo Shar $\left(27^{\circ} 53^{\prime} \mathrm{N}\right.$, $\left.86^{\circ} 28^{\prime} \mathrm{E}\right)$, Trakarding $\left(27^{\circ} 50^{\prime} \mathrm{N}, 86^{\circ} 28^{\prime} \mathrm{E}\right)$, Lirung $\left(28^{\circ} 14^{\prime} \mathrm{N}\right.$, $\left.85^{\circ} 33^{\prime} \mathrm{E}\right)$ and Khumbu $\left(27^{\circ} 57^{\prime} \mathrm{N}, \mathrm{E} 86^{\circ} 49^{\prime} \mathrm{E}\right)$, in the Nepal Himalaya (Fig. 1). Ripimo Shar and Trakarding Glaciers are located in the Rolwaling valley. There is one large glacial lake, Tsho Rolpa, at the terminus of Trakarding Glacier. Lirung Glacier is located in the Langtang valley, $60 \mathrm{~km}$ north-northeast of Kathmandu. The top of the glacier basin is the peak of Langtang Lirung mountain. Khumbu Glacier, which is located in the Khumbu region $150 \mathrm{~km}$ eastnortheast of Kathmandu, flows from Mount Everest (Sagarmatha; Qomolangma). We could not confirm the status of ice cliffs with other neighboring debris-covered glaciers, because there are some dangerous areas on the approach. Therefore, field data were limited.

Surveys of shores were carried out using a digital theodolite with a laser distance meter (SOKKIA SET2000) at glacial lakes on Ripimo-Shar, Trambau and Lirung glaciers. Since we did not conduct a field survey, the sizes of the two supraglacial ponds at Khumbu Glacier were measured using SPOT images taken on 7 November 1995. The images were georeferenced with control points taken from the Nepal topographic map, Sagamartha (Nepal: Survey Department, 1997). The horizontal distance error is estimated to be $\pm 20 \mathrm{~m}$ (one grid). Lakes with calving and non-calving ice cliffs were observed in order to determine whether or not there were floating ice blocks.

Usually, the fetch of lakes is defined as the distance along the open-water surface over which the wind blows in a given direction. Here fetch was defined as the maximum span length of the water surface of ponds along the glacier flow direction, since daytime valley winds are a characteristic of Himalayan glaciers. The fetch, area and further information on calving and non-calving in supraglacial ponds on debris-covered glaciers are summarized in Table 1.

Surface water temperatures along the shoreline were also measured manually using thermistor thermometry at almost all of the observed lakes. Measured water temperature and measurement date are also summarized in Table 1.

Figure 2 shows the frequency distribution of the fetch of supraglacial ponds with or without calving ice cliffs, based on the data in Table 1. Though no supraglacial pond was observed with a fetch from 40 to $80 \mathrm{~m}$, it is nevertheless clear that supraglacial ponds with a fetch of $<40 \mathrm{~m}$ have non-calving ice cliffs, while those with a fetch of $100 \mathrm{~m}$ have calving ice cliffs.

\section{MODEL SETTING}

The surface topography of debris-covered glaciers is characterized by rough terrain, and there are many ridges, cones, depressions and hollows (Iwata and others, 1980, 2000). Many supraglacial ponds are found in depressions, and some are surrounded by ridges and ice cliffs along the shore. In this case, wind speed at the water surface is variable depending on surrounding geomorphology even given a constant wind speed over the lake. Here we focus on the wind-speed difference under various fetches of lakes.

In the numerical simulation we assume there is a terminal moraine at the downstream end of the lake and an ice cliff at the upstream end of the lake (Fig. 3), since all expanding large glacial lakes (fetches of $>1 \mathrm{~km}$ ) in the Nepal Himalaya are located between a terminal moraine and a glacier ice cliff (Yamada, 1998). We fix the height and shape of the terminal moraine and ice cliff. Only the distance between the terminal moraine and the ice cliff is changed in order to focus on the effect of the water length on thermal undercutting.

We estimate subaqueous ice melting during both the open-water (melting) and freezing seasons. We assume the longitudinal profile of the supraglacial pond is a rectangle and is in contact with glacier ice, as shown in Figure 3. We assume there is no glacier ice at the bottom of the lake. Sakai and others (2003) reported that the bathymetric change of Imja glacial lake was concentrated at the glacier ice front and there was no bathymetric change at the debris-covered ice. Thus, a glacial lake only expands horizontally by the retreat of glacier ice. The topographical scale used in the model calculations is summarized in Figure 3. Two-dimensional calculations were carried out, and the lengths, $L$, of the longitudinal cross-sections of the supraglacial pond were 10 , 20, 50, 100, 200, 500, 1000 and $2000 \mathrm{~m}$. 

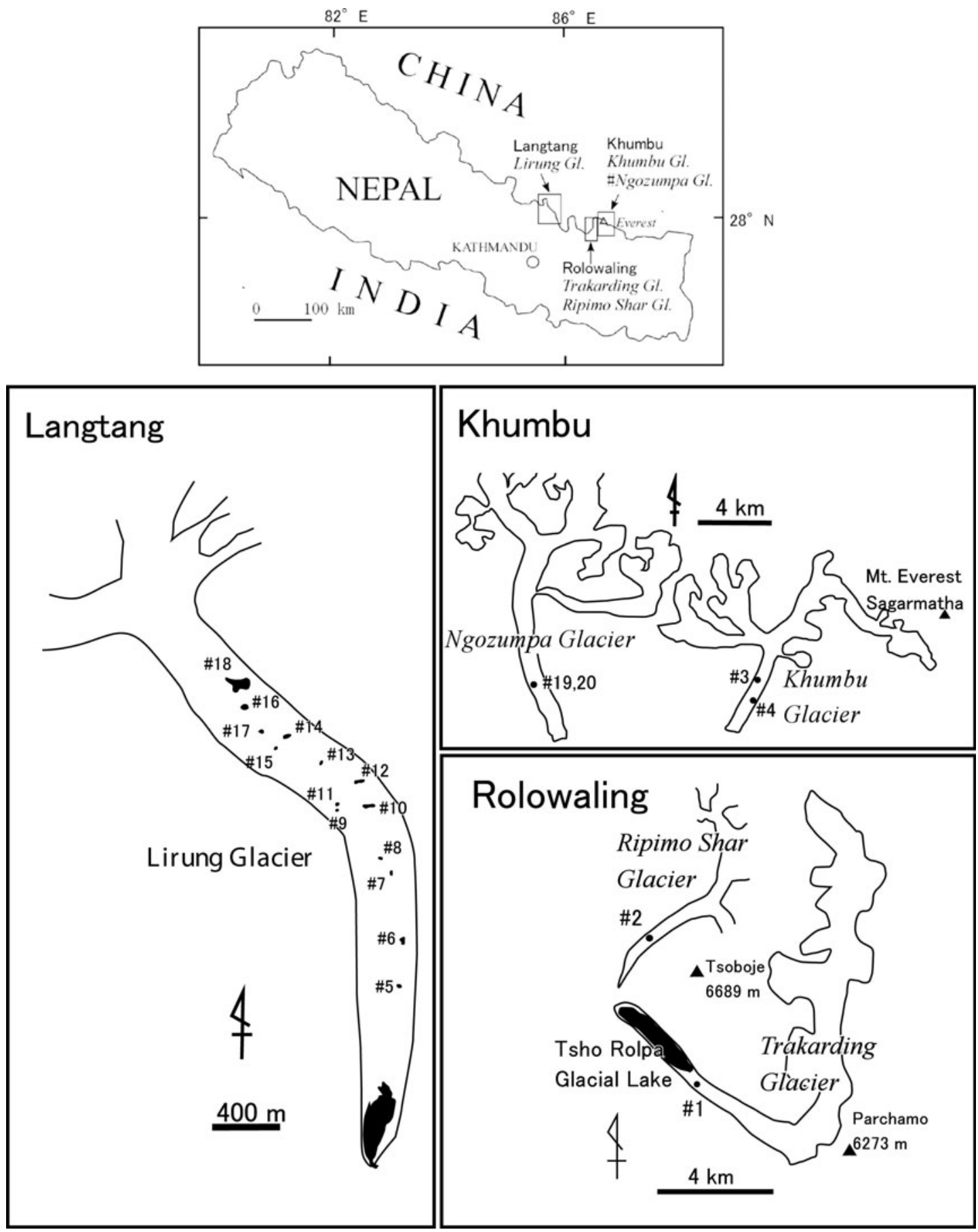

Fig. 1. Map showing locations of studied glaciers. All data at Ngozumpa Glacier are from Benn and others (2000). Locations of all observed ponds, as numbered and summarized in Table 1, are shown for each glacier.

\section{Melt season}

For the calculation of winds over the supraglacial ponds, the model calculation was carried out at the glacier terminus on a two-dimensional plane along the line of the wind direction as shown in Figure 3. Maximum height and length of the moraine were fixed at 10 and $120 \mathrm{~m}$ respectively, and its shape along the longitudinal cross-section was assumed triangular. The inclination of the moraine is $9.4^{\circ}$, the average for a debris surface (Aoki and Asahi, 1998). The height of the supra-aqueous ice cliff upstream of the lake (pond) was fixed at $20 \mathrm{~m}$, in line with observations. Wind blows horizontally over the lake from the moraine to the glacier ice cliff, and the wind speed was fixed at $2.4 \mathrm{~m} \mathrm{~s}^{-1}$, the average wind speed during the melt season at Tsho Rolpa (Yamada, 1998).
Numerical calculations of the wind velocity over the terrain and the wind-driven water current were performed as follows.

The continuity equation can be written as

$$
\frac{\partial u}{\partial x}+\frac{\partial v}{\partial y}=0
$$

where $x$ is a coordinate in the horizontal direction and $y$ in the vertical, while $u$ and $v$ are fluid speeds in the $x$ and $y$ directions. The conservation of momentum is expressed by the Reynolds-averaged Navier-Stokes equation

$$
\frac{\partial u_{i}}{\partial t}+u_{j} \frac{\partial u_{i}}{\partial x_{j}}=-\frac{1}{\rho} \frac{\partial P}{\partial x_{i}}+v \frac{\partial^{2} u_{i}}{\partial x_{j}^{2}}-\frac{\partial}{\partial x_{j}} \overline{u_{i}^{\prime} u_{j}^{\prime}} .
$$


Table 1. Summary of observed fetch, area, condition of ice cliffs and water temperature of supraglacial ponds. Locations of these ponds are shown by \# in Figure 1

\begin{tabular}{|c|c|c|c|c|c|c|c|c|c|c|}
\hline \multirow[t]{2}{*}{ No. } & \multirow[t]{2}{*}{ Glacier name } & \multirow{2}{*}{$\begin{array}{c}\text { Fetch } \\
\text { m }\end{array}$} & \multirow{2}{*}{$\begin{array}{l}\text { Area } \\
\mathrm{m}^{2}\end{array}$} & \multirow[t]{2}{*}{$\begin{array}{l}\text { Calving or } \\
\text { non-calving }\end{array}$} & \multirow[t]{2}{*}{ Survey date } & \multirow[t]{2}{*}{$\begin{array}{c}\text { Pond shore } \\
\text { measurement } \\
\text { method }\end{array}$} & \multirow[t]{2}{*}{ Source } & \multirow{2}{*}{$\begin{array}{c}\text { Water } \\
\text { temperature, } \\
T_{\mathrm{w}} \\
{ }^{\circ} \mathrm{C}\end{array}$} & \multirow[t]{2}{*}{$\begin{array}{c}\text { Measured date } \\
\text { of } T_{\mathrm{w}}\end{array}$} & \multirow[t]{2}{*}{$\begin{array}{c}T_{\mathrm{w}} \text { measurement } \\
\text { position }\end{array}$} \\
\hline & & & & & & & & & & \\
\hline 1 & Trakarding & 99 & 4075 & Non-calving & Jun. 1994 & Field survey & This study & 3.3 & 22 Jun. 1994 & Depth average \\
\hline 2 & Ripimo Shar & 276 & 20492 & Calving & Oct. 1994 & Field survey & This study & - & - & Freezing \\
\hline 4 & Khumbu & 94 & 6285 & Calving & Nov. 1995 & $\begin{array}{c}\text { Satellite image } \\
\text { (SPOT) }\end{array}$ & This study & 0.7 & 20 Oct. 1995 & Surface and edge \\
\hline 5 & Lirung & 16 & 244 & Non-calving & May-Jun. 1996 & Field survey & $\begin{array}{c}\text { Aoki and Asahi } \\
(1998)\end{array}$ & 3.9 & 08 May 1996 & Surface and edge \\
\hline 6 & Lirung & 37 & 737 & Non-calving & & & & 6.6 & 08 May 1996 & Surface and edge \\
\hline 7 & Lirung & 17 & 691 & Non-calving & & & & 2.7 & 09 May 1996 & Surface and edge \\
\hline 9 & Lirung & 8 & 98 & Non-calving & & & & 0.8 & 13 May 1996 & Surface and edge \\
\hline 10 & Lirung & 11 & 49 & Non-calving & & & & 2.0 & 13 May 1996 & Surface and edge \\
\hline 11 & Lirung & 11 & 614 & Non-calving & & & & 2.7 & 13 May 1996 & Surface and edge \\
\hline 12 & Lirung & 12 & 191 & Non-calving & & & & 4.6 & 13 May 1996 & Surface and edge \\
\hline 13 & Lirung & 11 & 191 & Non-calving & & & & 5.7 & 15 Jun. 1996 & Surface and edge \\
\hline 14 & Lirung & 7 & 489 & Non-calving & & & & 2.5 & 15 Jun. 1996 & Surface and edge \\
\hline 15 & Lirung & 10 & 83 & Non-calving & & & & 2.1 & 15 Jun. 1996 & Surface and edge \\
\hline 16 & Lirung & 34 & 774 & Non-calving & & & & - & - & \\
\hline 17 & Lirung & 8 & 138 & Non-calving & & & & 2.4 & 11 May 1996 & Surface and edge \\
\hline 18 & Lirung & 105 & 6789 & Calving & & & & 4.0 & 11 May 1996 & Surface and edge \\
\hline 19 & Ngozumpa & 100 & 12980 & Calving & Oct. 1998 & Field survey & $\begin{array}{c}\text { Benn and others } \\
(2000)\end{array}$ & - & - & \\
\hline 20 & Ngozumpa & 139 & 29917 & Calving & Oct. 1999 & Field survey & $\begin{array}{c}\text { Benn and others } \\
(2000) \text { (southern } \\
\text { part only) }\end{array}$ & - & - & \\
\hline
\end{tabular}

Here $u$ and $u^{\prime}$ denote the mean velocity and the velocity fluctuations of the flow. In Cartesian coordinates $\left(x_{i}\right.$ represents $(x, y)$ for $i=1,2), u_{i}$ has two components of fluid velocity $(u, v) . P$ is the fluid pressure, $\rho$ is its density and $\nu$ is its kinematic viscosity. These parameters are assumed to be constant: the air temperature was $5^{\circ} \mathrm{C}$ and the water temperature $2^{\circ} \mathrm{C}$. For the necessary closing of the turbulent equation we use $k-\varepsilon$ equations.

First, the wind velocity distributions were calculated until the distribution reached the steady state over the given terrain. The distributions of water circulation were then calculated using the simulated wind velocity at the water

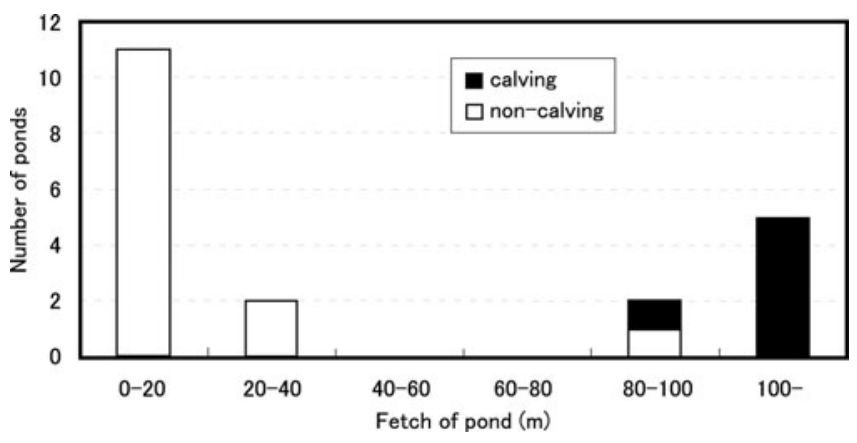

Fig. 2. Frequency distribution of fetch of supraglacial ponds with calving or non-calving ice cliffs. surface until the water circulation reached a steady state. Boundary conditions at the lake bottom and side wall were non-slip. The horizontal grid length was divided equally and the vertical grid size decreased geometrically downward. The grid sizes near the moraine, the lake and the glacier ice cliff were set small enough to correspond to the total calculation domain (e.g. the horizontal length of each grid was $1 \mathrm{~m}$, and the vertical length at the water surface was $1 \mathrm{~cm}$ when the fetch was $100 \mathrm{~m}$ ).

For the melt rate of an iceberg, Weeks and Campbell (1973) applied an equation for the average heat-transfer coefficient of fully turbulent flow of a fluid over a flat

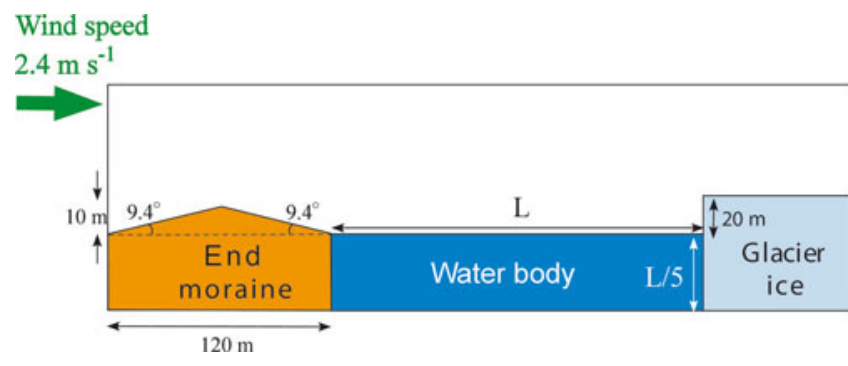

Fig. 3. Model-setting topography (cross-section of glacier terminus with pond) for calculation of wind-velocity and water-current distributions. In numerical simulations, the topography of the terminal moraine and glacier terminal super-aqueous ice cliff was fixed, and only length and depth of the lake (pond) were varied. 

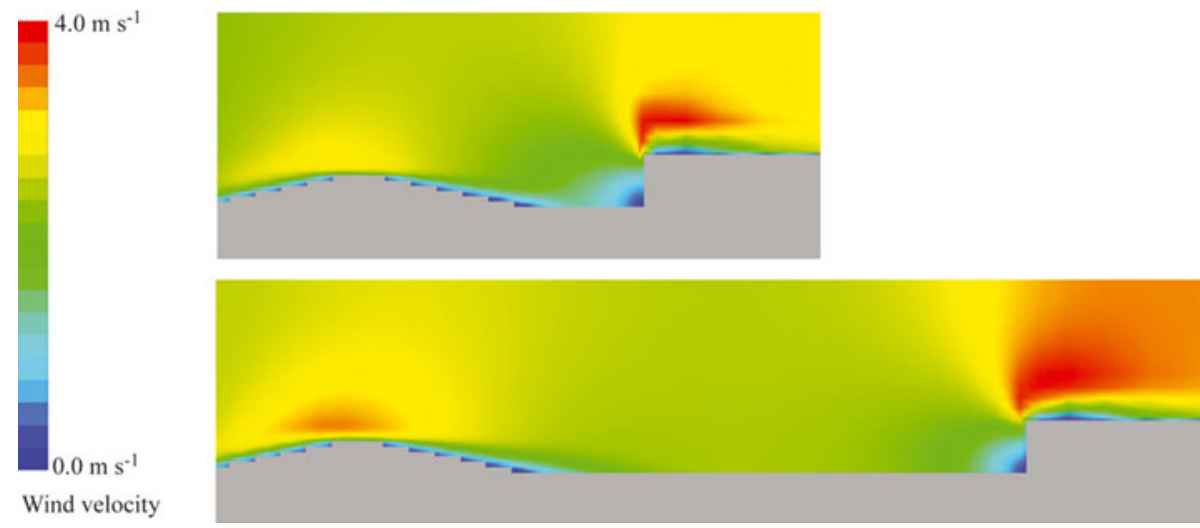

Fig. 4. Results of wind-velocity distribution when fetches were $50 \mathrm{~m}$ (above) and $500 \mathrm{~m}$ (below).

plate. Here we adopt the equation to denote the melt rate in pure water for application to a supraglacial pond or lake as follows:

$$
S=7.14 \times 10^{-6}\left(\frac{V^{0.8}}{\left(\frac{L}{5}\right)^{0.2}}\right) \Delta T,
$$

where $S$ is melt rate $\left(\mathrm{m} \mathrm{s}^{-1}\right)$ and $V$ is water velocity at the ice cliff $\left(\mathrm{m} \mathrm{s}^{-1}\right)$. The constant $\left(7.14 \times 10^{-6}\right)$ can be obtained from the coefficient of heat transfer, dynamic viscosity, specific heat and kinematic viscosity of water.

Water temperatures were assumed to be $1,2,4$ and $6^{\circ} \mathrm{C}$ in accordance with measured values (Table 1). Simulated water currents directed downward at the subaqueous ice cliff at depth $1 \mathrm{~cm}$ at each fetch are used to calculate the subaqueous ice-cliff melt.

Valley winds blow from the end moraine to the glacier. Thus, the surface water of a supraglacial lake or pond flows down at the subaqueous ice cliff, and the contact length of the ice is equal to the depth of the lake or pond, since we assume that the lake is rectangular.

For the calculation of annual thermal undercutting, the melt season is assumed to last for 4 months, based on the fact that at Tsho Rolpa glacial lake from 1994 to 1995 the observed surface temperature of $\sim 5^{\circ} \mathrm{C}$ was maintained from June to September yet it was $<3^{\circ} \mathrm{C}$ from October to the following May.

\section{Freeze season}

During the freezing season, subaqueous ice melt was also estimated by numerical calculation. We assume that heat for a submerged ice-melting rate is expressed by Equation (3) with $0^{\circ} \mathrm{C}$ set for the submerged ice temperature. The water velocity is assumed to be $0.02 \mathrm{~m} \mathrm{~s}^{-1}$, since the maximum measured water current in the ice-covered lake was $0.018 \mathrm{~m} \mathrm{~s}^{-1}$ according to Petrov and others (2007). There is no heat exchange except between heat storage in the lake water, and the latent heat for submerged ice melt. Thus, the lake volume changes according to the submerged glacier ice melting, and water temperature changes according to the volume expansion of the lake and latent heat for submerged ice melt. The winter season is assumed to be 8 months since we observed that the ice-cover period began in October at the pond of Khumbu Glacier in 1995 and there was no ice at the end of May at the pond of Lirung Glacier in 1996. The calculation interval was 1 day.

\section{MODEL RESULTS}

Calculated wind velocity distributions with fetches of 50 and $500 \mathrm{~m}$ are shown in Figure 4. Wind velocity over the ice cliff is greater than the upper wind speed of $2.4 \mathrm{~m} \mathrm{~s}^{-1}$ because of airflow convergence due to the obstructing ice cliff. Relatively light wind blows at the foot of the supra-aqueous ice cliff and at the top of the ice cliff since the airflow forms a bolster eddy along the base.

Wind speed over the water surface, from the end moraine to the glacier ice cliff, is shown in Figure 5. Wind speed along the water surface with the fetch of $10 \mathrm{~m}$ is nearly zero due to the obstructing end moraine. On the other hand, maximum wind speed along the water surface abruptly increases to $1.4 \mathrm{~m} \mathrm{~s}^{-1}$ when the fetch is $50 \mathrm{~m}$, and reverse flow even develops near the end moraine because of the establishment of a lee eddy. Maximum wind speed along the water surface attains a limit $\left(2.4 \mathrm{~m} \mathrm{~s}^{-1}\right)$ at a fetch of $200 \mathrm{~m}$.

The horizontal component of the calculated water current along the subaqueous ice cliff at depth $1 \mathrm{~cm}$ is $V$ in Equation (3). The calculated water velocity for each fetch length is shown in Figure 6 . The vertical water velocity increases with the fetch since the wind over the water surface increases until a fetch of $1000 \mathrm{~m}$. However, the vertical water velocity peaked at a fetch of $1000 \mathrm{~m}$ and it does not increase with a fetch of more than $1000 \mathrm{~m}$.

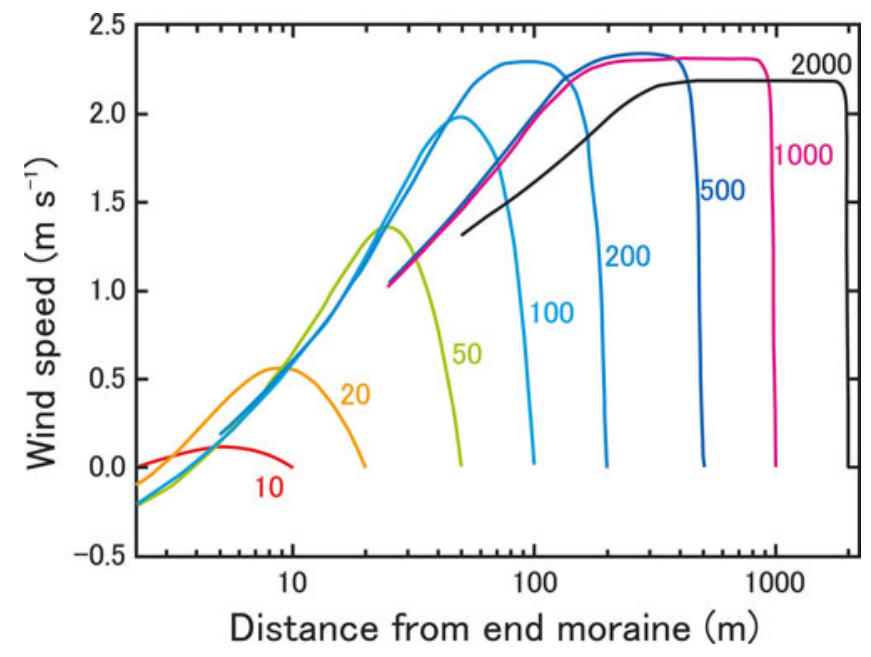

Fig. 5. Results of numerical calculation of wind speed over lake water surface. Numbers indicate fetch of lakes in meters. 


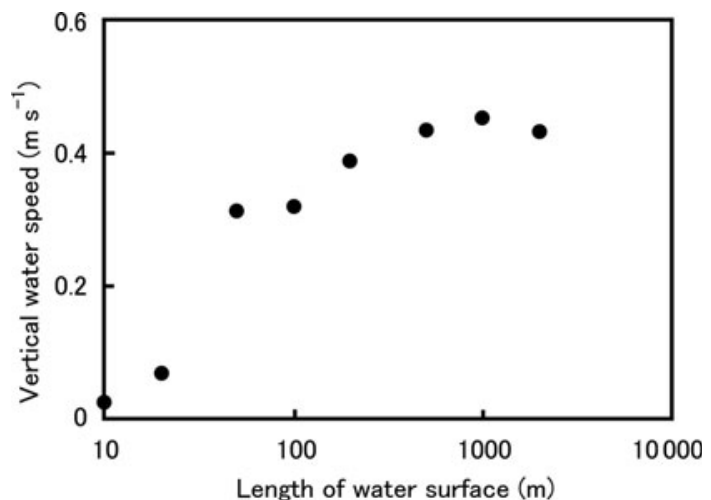

Fig. 6. Calculated vertical water-flow velocity at the ice cliff at $1 \mathrm{~cm}$ depth. All velocities are positive if directed downward. These are used for the calculation of subaqueous ice-cliff melt (Equation (3)).

Figure 7 shows the calculated summer (open-water), winter (ice-covered) and annual subaqueous ice-cliff melt at various fetches for water temperatures of $1,2,4$ and $6^{\circ} \mathrm{C}$.

The calculated subaqueous ice-cliff melt amount during the open-water period (Fig. 7a) rapidly increases to a fetch of $50 \mathrm{~m}$, since the wind-driven water current rapidly develops from a fetch of 20 to $50 \mathrm{~m}$ as shown in Figure 5. It gradually decreases with a fetch longer than $50 \mathrm{~m}$. Increasing lake depth, $L$, causes the melt rate of the subaqueous ice cliffs to decrease as shown in Equation (3).

The melt amount at the submerged ice during the icecovered period increases with initial water temperature. It increases with lake size up to a lake length of $500 \mathrm{~m}$, but then decreases with lake size.

The subaqueous ice-cliff melt during the summer melt season accounts for most of the annual melt amount. The annual subaqueous ice melt increases rapidly when the fetch is $\sim 30 \mathrm{~m}$.

\section{DISCUSSION}

Overhanging ice cliffs can be formed when subaqueous ice melt is greater than supra-aqueous ice-cliff melt. Average observed supra-aqueous ice-cliff melt during the melt season was $4-14 \mathrm{~m} \mathrm{a}^{-1}$ at Lirung Glacier (Sakai and others, 1998, 2002). Comparing the observed maximum supra-aqueous ice-cliff melt $\left(14 \mathrm{~m} \mathrm{a}^{-1}\right)$ with the calculated subaqueous ice melt, an overhanging ice cliff can be formed when the fetch is $>20 \mathrm{~m}$ and water temperature is $2-4^{\circ} \mathrm{C}$. Almost all water temperature observations ranged between 2 and $4^{\circ} \mathrm{C}$.

Figure 2 shows that ice cliffs at supraglacial lakes with $<40 \mathrm{~m}$ fetch did not exhibit calving ice, while calving ice was observed at lakes with an $80 \mathrm{~m}$ fetch. Numerical calculations, however, show that overhanging ice will form at a lake with $>20 \mathrm{~m}$ fetch if the water temperature is $2-4^{\circ} \mathrm{C}$. The discrepancy between observations and calculations of the fetch required for the onset of calving might be explained by a non-heterogeneous water temperature distribution in the lake.

Based on field observations, Röhl (2006) concluded that submerged ice melting was controlled not only by water temperature and circulation but also by cliff geometry, debris supply and water-level fluctuations, making thermal undercutting more complicated. Eijpen and others (2003) found that the ice melt calculated using Weeks and Campbell (1973) (Equation (3)) was much smaller than the
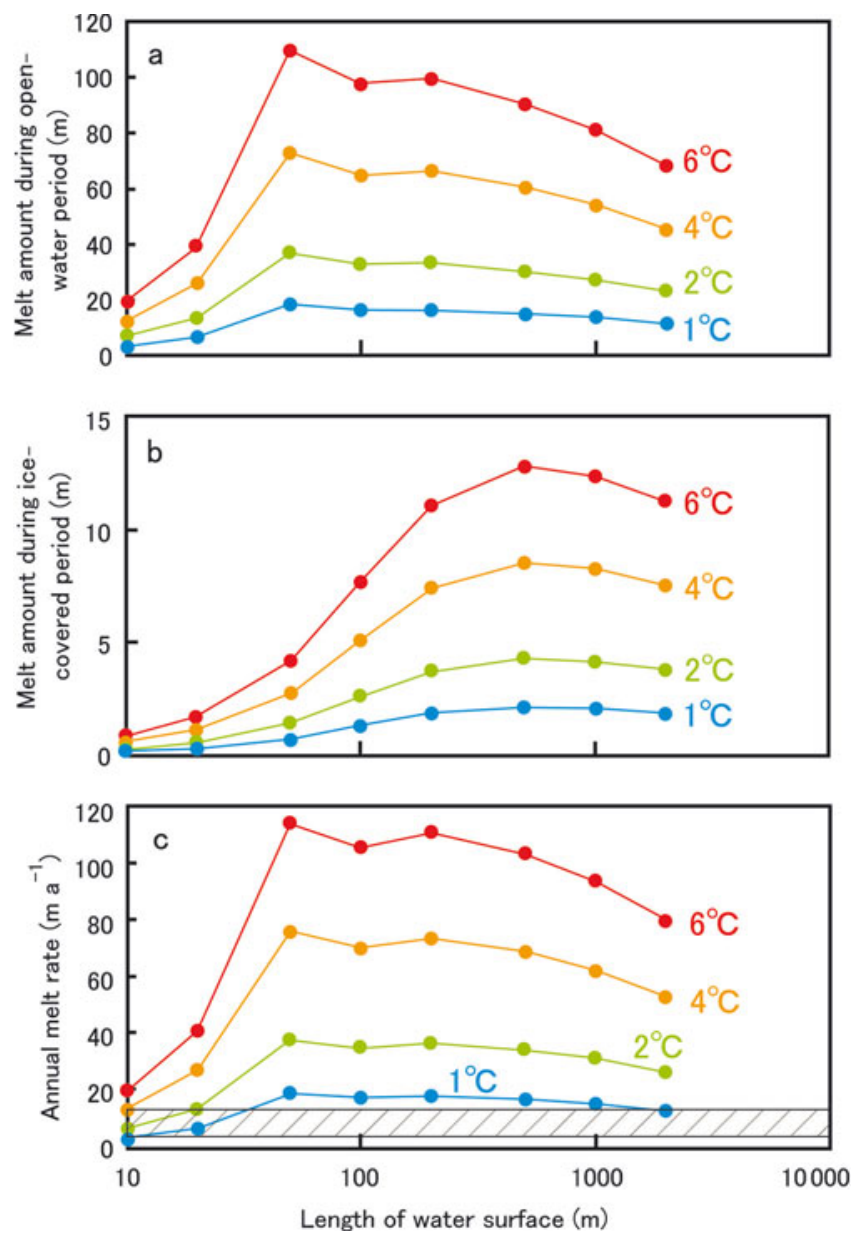

Fig. 7. Dependence on length of water surface (fetch) at different temperatures for (a) melt amount during open-water period, (b) melt amount during ice-covered period and (c) annual melt rate. Shaded area in (c) indicates range of observed supra-aqueous ice-cliff melt rate $\left(4-14 \mathrm{~m} \mathrm{a}^{-1}\right)$ (Sakai and others, 1998).

ice melt measured in their laboratory experiments. On the other hand, our observed conditions for the onset of ice-cliff calving in supraglacial ponds are consistent with our numerical results using Equation (3), which estimates the effects of water temperature and current on submerged icecliff melt rate well.

Figure 8 shows glacial lake area change in the Nepal and Bhutan Himalaya over the past 50 years. Glacial lake areas have expanded up to the lateral moraine for all lakes except Thorthomi Tsho. Glacier terminus retreat rate depends on the calving rate, ice-cliff melt rate and glacier terminus velocity. Here we can neglect glacier velocity since Quincey and others (2007) indicate that surface velocity is $<10 \mathrm{~m} \mathrm{a}^{-1}$ at glaciers terminating in a large glacial lake. The ice-cliff melt rate is also negligible because the measured melt rate is $<15 \mathrm{~m} \mathrm{a}^{-1}$ (Sakai and others, 1998), much less than the calving rate. Hence, glacial lake expansion is caused mainly by horizontal glacier ice retreat, i.e. calving of glacier ice.

Supraglacial lakes ranging from $20 \mathrm{~m}$ to $1 \mathrm{~km}$ in radius length are scattered around the debris-covered glacier at Thorthomi Tsho in Bhutan (Ageta and others, 2000). In our field research in 1998, we observed that the lakes in the middle of the glacier were enclosed by ice cliffs. Their areas increased dramatically between 1990 and 1993 (Fig. 8). The rapid increase in lake area should reflect the increase in annual calving rate (i.e. annual submerged ice melt rate) due 


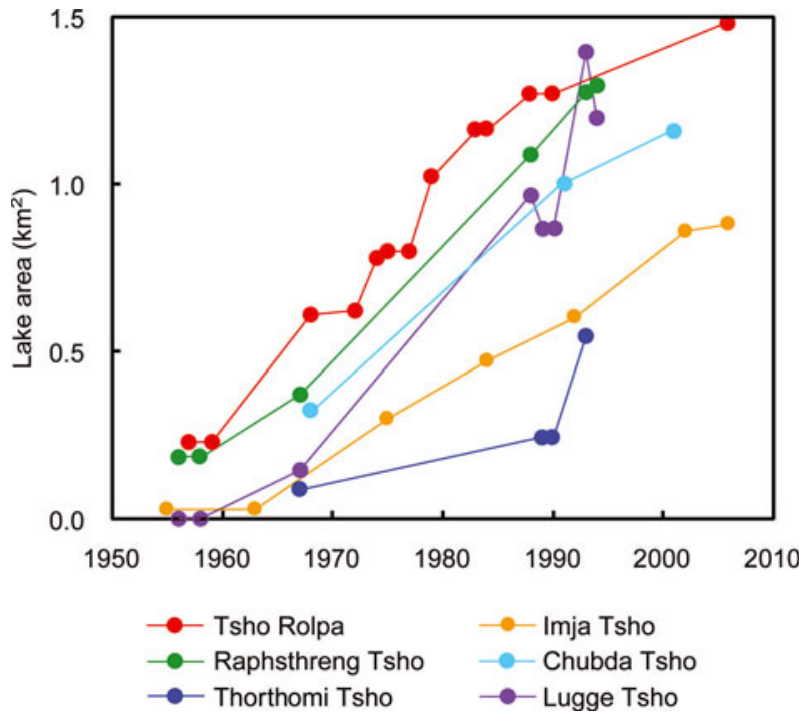

Fig. 8. Area change of moraine-dammed glacial lakes in the Himalaya (after Komori and others, 2004).

to enlargement of the fetch as indicated by our model calculations.

The area expansion rate at Tsho Rolpa glacial lake decreased between 1990 and 2005 (Fig. 8) because the lake level was lowered artificially in order to mitigate GLOF hazards in 1998-2000 (Reynolds, 1999; Rana and others, 2000). At Lugge glacial lake, a GLOF occurred in 1994, and the lake level decreased (Iwata and others, 2002; Fujita and others, 2008).

Area expansion rates have been almost constant except when events have occurred involving lowering of the water level. The area of these lakes increases only by glacier icecliff retreat since they have already expanded to the lateral moraine, i.e. the area expansion rate is matched by the glacier terminus retreat rate. Calculated water current (Fig. 6) increases until a fetch of $1000 \mathrm{~m}$, then remains constant due to the loss of the screening effect of the end moraine. The expansion of glacial lakes reflects the fact that ice calving of the glacier occurs by submerged ice melt which is caused by wind-driven water currents. On the other hand, the calculated melt rate decreased with the fetch when the fetch was $>50 \mathrm{~m}$, since the submerged icecliff height ( $L / 5$ in Fig. 3) increased with the fetch (Fig. 7C). In further study, we will examine the height, $L / 5$, with the expansion of the lake, and the adjustability of Equation (3).

The average heights of the end moraine and the dead-ice area located downstream of Imja glacial lake are higher than for Tsho Rolpa glacial lake. Chikita (2007), using numerical simulations, indicated that the wind velocity over Imja glacial lake was less than that over Tsho Rolpa glacial lake because of the screening effect of the end moraine and dead-ice portion. We can thus explain the difference in lake area expansion between Tsho Rolpa and Imja glacial lakes by the difference in ice melt rates derived from the difference in wind-driven water current.

Figure 9 shows the ice cliff abutting the glacial lake at Tsho Rolpa Glacier. Debris covered the ice in a depression at the foot of the ice cliff in June 1994 (Fig. 9a), although there was no ice at the foot of the ice cliff in May 1995 (Fig. 9b). Step-like topography at the glacier ice touching a glacial lake has been observed at Tsho Rolpa glacial lake by the Advanced Spaceborne Thermal Emission and Reflection
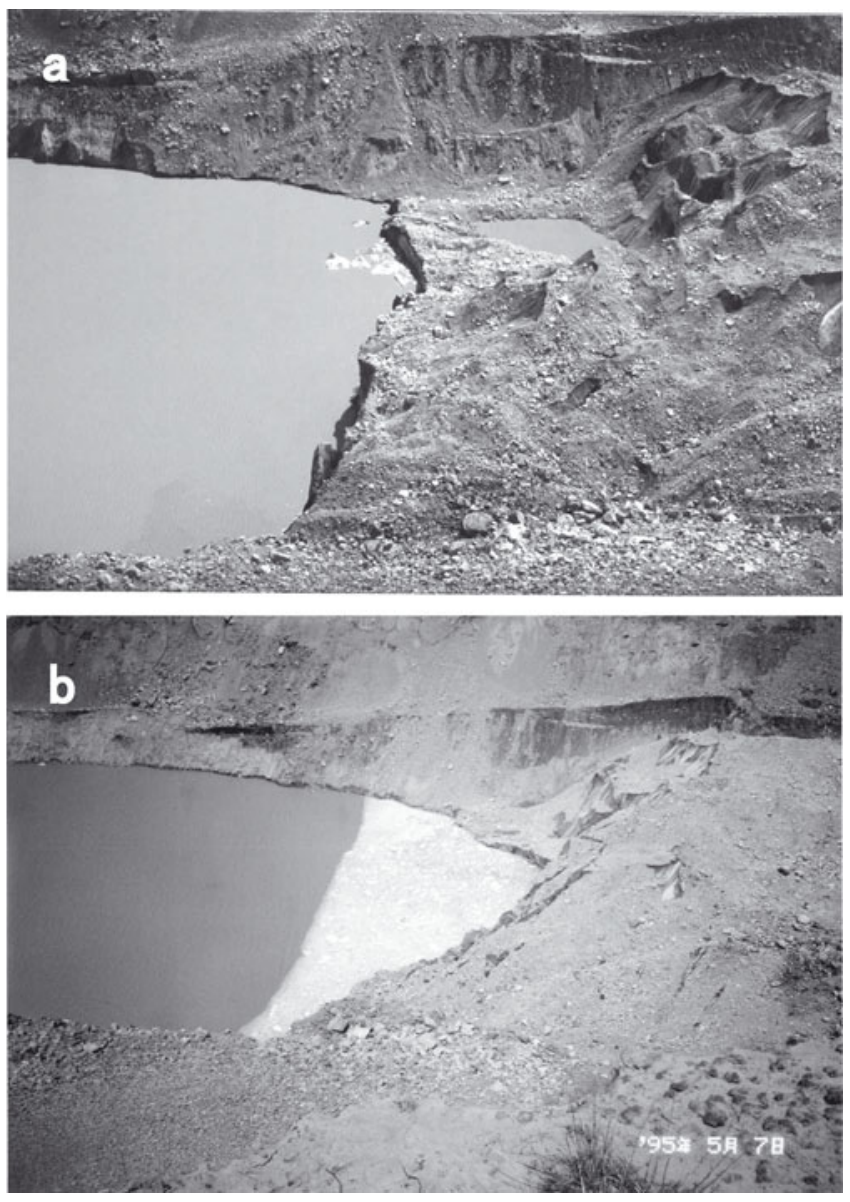

Fig. 9. Photos of Tsho Rolpa glacial lake and the terminus of Trakarding Glacier, taken in (a) November 1994 and (b) May 1995.

Radiometer (ASTER) satellite images taken on 10 November 2004 and QuickBird satellite images taken on 21 February 2005. We also observed similar topography during field research at Imja glacial lake in November 2001 and April 2002 (Sakai and others, 2007). Step-like topography at the glacier ice touching a glacial lake would indicate that glacial lake expansion was caused by submerged ice melting and the subsiding supra-aqueous ice. We conclude that thermal undercutting leading to subsiding overhanging ice is an important process in the expansion mechanism of glacial lakes in the Himalaya.

\section{CONCLUSION}

Wind-driven water currents were simulated at various-sized supraglacial lakes (ponds) along a longitudinal cross-section. We found that calving at supraglacial ponds occurs at a fetch of $>20-30 \mathrm{~m}$, by thermal undercutting when the water temperature is within a given range $\left(2-4^{\circ} \mathrm{C}\right)$, since the annual subaqueous ice-cliff melt becomes larger than the supra-aqueous ice-cliff melt due to development of valley wind-driven water current.

Analysis of the measured size of supraglacial ponds and field observations of ice cliffs surrounding those ponds revealed that ice-cliff calving occurs when a pond is $>\sim 80 \mathrm{~m}$ long. Simulations for calculation of thermal undercutting supported the idea that calving occurred at ice cliffs at supraglacial ponds when the fetch of the ponds exceeded 20-30 m. These results show that wind-driven water currents 
are a significant cause of the calving process at glacial lakes in the Himalaya. Our simulation covers a gap with no observed data, with a fetch of $40-80 \mathrm{~m}$. Further field observation of calving will be helpful for understanding the process of glacial lake expansion.

The observed expansion rates of glacial lakes indicate that the areas of relatively small supraglacial lakes enclosed by ice cliffs have increased dramatically, while the areas of large glacial lakes, which had already expanded to the lateral moraine, also increased due to glacier terminus retreats. The expansion of glacial lakes reflects the fact that glacier ice calving occurs by submerged ice melt which is caused by wind-driven water currents. For future assessment of supraglacial lakes, we must examine not only large glacial lakes of more than a few $\mathrm{km}$, but also small lakes of $<100 \mathrm{~m}$ radius, since they have the potential to expand rapidly.

\section{ACKNOWLEDGEMENTS}

We thank O. Bajracharya and other staff members in the Department of Hydrology and Meteorology, Ministry of Science and Technology, Government of Nepal, for generous assistance and cooperation in our research activity. We also thank M. Kirkbride and K. Röhl for valuable advice and comments. This research was supported by a Grant-in-Aid for Scientific Research (No. 19253001) from the Ministry of Education, Culture, Sports, Science and Technology, Japan, and the Japan Science and Technology Agency-Japan International Cooperation Agency within the framework of the Science and Technology Research Partnership for Sustainable Development (SATREPS).

\section{REFERENCES}

Ageta, Y., S. Iwata, H. Yabuki, N. Naito, A. Sakai and S. Narama. 2000. Expansion of glacier lakes in recent decades in the Bhutan Himalayas. IAHS Publ. 264 (Symposium at Seattle 2000 Debris-Covered Glaciers), 165-175.

Aoki, T. and K. Asahi. 1998. Topographical map of the ablation area of the Lirung Glacier in the Langtang Valley, Nepal Himalaya. Bull. Glacier Res., 16, 19-31.

Benn, D.I., S. Wiseman and C.R. Warren. 2000. Rapid growth of a supraglacial lake, Ngozumpa Glacier, Khumbu Himal, Nepal. IAHS Publ. 264 (Symposium at Seattle 2000 - Debris-Covered Glaciers), 177-185.

Benn, D.I., S. Wiseman and K.A. Hands. 2001. Growth and drainage of supraglacial lakes on the debris-mantled Ngozumpa Glacier, Khumbu Himal, Nepal. J. Glaciol., 47(159), 626-638.

Benn, D.I., N.R.J. Hulton and R.H. Mottram. 2007. 'Calving laws', 'sliding laws' and the stability of tidewater glaciers. Ann. Glaciol., 46, 123-130.

Chikita, K.A. 2007. Topographic effects on the thermal structure of Himalayan glacial lakes: observations and numerical simulation of wind. J. Asian Earth Sci., 30(2), 344-352.

Chikita, K., T. Yamada, A. Sakai and R.P. Ghimire. 1997. Hydrodynamic effects on the basin expansion of Tsho Rolpa glacier lake in the Nepal Himalaya. Bull. Glacier Res., 15, 59-69.

Chikita, K., J. Jha and T. Yamada. 1999. Hydrodynamics of a supraglacial lake and its effect on the basin expansion: Tsho Rolpa, Rolwaling Valley, Nepal Himalaya. Arct. Antarct. Alp. Res., 31(1), 58-70.

Costa, J.E. and R.L. Schuster. 1988. The formation and failure of natural dams. Geol. Soc. Am. Bull., 100(7), 1054-1068.

Diolaiuti, G., M.P. Kirkbride, C. Smiraglia, D.I. Benn, C. D'Agata and L. Nicholson. 2005. Calving processes and lake evolution at
Miage glacier, Mont Blanc, Italian Alps. Ann. Glaciol., 40 207-214.

Eijpen, K.J., C.R. Warren and D.I. Benn. 2003. Subaqueous melt rates at calving termini: a laboratory approach. Ann. Glaciol. 36, 179-183.

Fujita, K., R. Suzuki, T. Nuimura and A. Sakai. 2008. Performance of ASTER and SRTM DEMs, and their potential for assessing glacial lakes in the Lunana region, Bhutan Himalaya. J. Glaciol., 54(185), 220-228.

Haresign, E. and C.R. Warren. 2005. Melt rates at calving termini: a study at Glaciar León, Chilean Patagonia. In Harris, C. and J.B. Murton, eds. Cryospheric systems: glaciers and permafrost. London, Geological Society. (Geological Society Special Publication 242.)

Inoue, J. 1976. Climate of Khumbu Himal. Seppyo, J. Jpn. Soc. Snow Ice, Special Issue 38, 66-73.

Iwata, S., O. Watanabe and H. Fushimi. 1980. Surface morphology in the ablation area of the Khumbu Glacier. Seppyo, J. Jpn. Soc. Snow Ice, Special Issue 41, 9-17.

Iwata, S., T. Aoki, T. Kadota, K. Seko and S. Yamaguchi. 2000. Morphological evolution of the debris cover on Khumbu Glacier, Nepal, between 1978 and 1995. IAHS Publ. 264 (Symposium at Seattle, 2000 - Debris-Covered Glaciers), $3-11$.

Iwata, S., Y. Ageta, N. Naito, A. Sakai and C. Narama. 2002. Glacial lakes and their outburst flood assessment in the Bhutan Himalaya. Global Environ. Res., 6(1), 3-17.

Josberger, E.G. and S. Neshyba. 1980. Iceberg melt-driven convection inferred from field measurements of temperature. Ann. Glaciol., 1, 113-117.

Kirkbride, M.P. 1993. The temporal significance of transitions from melting to calving termini at glaciers in the central Southern Alps of New Zealand. Holocene, 3(3), 232-240.

Kirkbride, M.P. and C.R. Warren. 1997. Calving processes at a grounded ice cliff. Ann. Glaciol., 24, 116-121.

Komori, J., D.R. Gurung, S. Iwata and H. Yabuki. 2004. Variation and lake expansion of Chubda Glacier, Bhutan Himalayas, during the last 35 years. Bull. Glaciol. Res., 21, 49-55.

Lanzhou Institute of Glaciology and Geocryology (LIGG), Water and Energy Commission Secretariat (WECS) and Nepal Electricity Authority (NEA). 1988. Report on first expedition to glaciers and glacier lakes in the Pumqu (Arun) and Poiqu (Bhote-un Koshi) river basins, Xizang (Tibet), China, ed. Liu, C. and C.K. Sharma. Beijing, Science Press.

Liestøl, O. 1956. Glacier dammed lakes in Norway. Nor. Geogr. Tidsskr., 15(3-4), 122-149.

Lliboutry, L. 1977. Glaciological problems set by the control of dangerous lakes in Cordillera Blanca, Peru: II. Movement of a covered glacier embedded within a rock glacier. J. Glaciol., 18(79), 255-273.

Lliboutry, L., B.M. Arnao, A. Pautre and B. Schneider. 1977a. Glaciological problems set by the control of dangerous lakes in Cordillera Blanca, Peru: I. Historical failures of morainic dams, their causes and prevention. J. Glaciol., 18(79), 239-254.

Lliboutry, L., B.M. Arnao and B. Schneider. 1977b. Glaciological problems set by the control of dangerous lakes in the Cordillera Blanca, Peru: III. Study of moraines and mass balances at Safuna. J. Glaciol., 18(79), 275-290.

Martin, S., E. Josberg and P. Kaufmann. 1978. Wave-induced heat transfer to an iceberg. In Husseiny, A.A., ed. Iceberg utilization. New York, Pergamon Press, 260-263.

Moribayashi, S. 1974. On the characteristics of the glaciers in the Himalaya and their recent variations. Seppyo, J. Jpn. Soc. Snow Ice, 36(1), 11-21. [In Japanese with English summary.]

Nepal: Survey Department. 1997. Sagamartha. (Scale 150 000.) Kathmandu, HM Government of Nepal. Survey Department. (Sheet No. 2786 04.)

Petrov, M.P., A.Yu. Terzhevik, R.E. Zdorovennov and G.E. Zdorovennova. 2007. Motion of water in an ice-covered shallow lake. Water Resour., 34(2), 113-122. 
Post, A. and L.R. Mayo. 1971. Glacier dammed lakes and outburst floods in Alaska. USGS Hydrol. Invest. Atlas HA-455.

Quincey, D.J., R.M. Lucas, S.D. Richardson, N.F. Glasser, M.J. Hambrey and J.M. Reynolds. 2005. Optical remote sensing techniques in high-mountain environments: application to glacial hazards. Progr. Phys. Geogr., 29(4), 475-505.

Quincey, D.J. and 6 others. 2007. Early recognition of glacial lake hazards in the Himalaya using remote sensing datasets. Global Planet. Change, 56(1-2), 137-152.

Rana, B., A.B. Shrestha, J.M. Reynolds, R. Aryal, A.P. Pokhrel and K.P. Budhathoki. 2000. Hazard assessment of the Tsho Rolpa Glacier Lake and ongoing remediation measures. J. Nepal Geol. Soc., 22, 563-570.

Reynolds, J.M. 1999. Glacial hazard assessment at Tsho Rolpa, Rolwaling, central Nepal. Q. J. Eng. Geol., 32(3), 209-214.

Richardson, S.D. and J.M. Reynolds. 2000. An overview of glacial hazards in the Himalayas. Quat. Int., 65/66(1), 31-47.

Röhl, K. 2006. Thermo-erosional notch development at fresh-watercalving Tasman Glacier, New Zealand. J. Glaciol., 52(177), 203-213.

Röhl, K. 2008. Characteristics and evolution of supraglacial ponds on debris-covered Tasman Glacier, New Zealand. J. Glaciol., 54(188), 867-880.

Russell-Head, D.S. 1980. The melting of free-drifting icebergs. Ann. Glaciol., 1, 119-122.

Sakai, A., M. Nakawo and K. Fujita. 1998. Melt rate of ice cliffs on the Lirung Glacier, Nepal Himalayas, 1996. Bull. Glacier Res., 16, 57-66.

Sakai, A., K. Chikita and T. Yamada. 2000a. Expansion of a moraine-dammed glacial lake, Tsho Rolpa, in Rolwaling Himal, Nepal Himalaya. Limnol. Oceanogr., 45(6), 1401-1408.
Sakai, A., N. Takeuchi, K. Fujita and M. Nakawo. 2000b. Role of supraglacial ponds in the ablation process of a debris-covered glacier in the Nepal. IAHS Publ. 264 (Symposium at Seattle 2000 - Debris-Covered Glaciers), 119-130.

Sakai, A., M. Nakawo and K. Fujita. 2002. Distribution characteristics and energy balance of ice cliffs on debris-covered glaciers, Nepal Himalaya. Arct. Antarct. Alp. Res., 34(1), 12-19.

Sakai, A., T. Yamada and K. Fujita. 2003. Volume change of Imja glacial lake in the Nepal Himalayas. In Proceedings of the International Symposium on Disaster Mitigation and Basin Wide Water Management, 7-10 December 2003, Niigata, Japan. Nagaoka, Akatsuki Publishing Co., 556-561.

Sakai, A. and 8 others. 2007. Topographical survey of end-moraine and dead ice area at the Imja Glacial Lake in 2001 and 2002. Bull. Glaciol. Res., 24, 29-36.

Thórarinsson, S. 1939. The ice dammed lakes of Iceland with particular reference to their values as indicators of glacier oscillations. Geogr. Ann., 21(3-4), 216-242.

Thórarinsson, S. 1957. The jökulhlaup from the Katla area in 1955 compared with other jökulhlaups in Iceland. Jökull, 7, 21-25.

Warren, C.R. and M.P. Kirkbride. 1998. Temperature and bathymetry of ice-contact lakes in Mount Cook National Park, New Zealand. New Zeal. J. Geol. Geophys., 41(2), 133-143.

Warren, C.R. and M.P. Kirkbride. 2003. Calving speed and climatic sensitivity of New Zealand lake-calving glaciers. Ann. Glaciol., 36, 173-178.

Weeks, W.F. and W.J. Campbell. 1973. Icebergs as a fresh-water source: an appraisal. J. Glaciol., 12(65), 207-233.

Yamada, T. 1998. Glacier lake and its outburst flood in the Nepal Himalaya. Tokyo, Japanese Society of Snow and Ice. Data Center for Glacier Research.

MS received 19 September 2008 and accepted in revised form 26 September 2009 